\title{
Empirical Study on the Debt Maturity Structure Based on the
}

\section{Macroeconomic Variables}

\author{
Yanhui Wang, Yexin Sun \& Qingjun Lv \\ School of Business Administration, Northeastern University, Shenyang 110104, China \\ E-mail: yhwang@mail.neu.edu.cn
}

\begin{abstract}
By the agency costs theory and the expectation theory, the relationships between the enterprise debt maturity structure and the economic aggregate indexes such as the economic development level, the inflation, the money supply, and the macro-tax burden are empirically tested, and the result shows that the GDP growth rate and the macro-tax burden present the positively correlative relationship with the enterprise debt maturity, and the inflation and the money supply present the negatively correlative relationship with the enterprise debt maturity, and the both relativities are significant, which indicates that the debt maturity structure of Chinese listed companies is significantly influenced not only by many interior characteristics such as the enterprise size, the assets maturity, and the growth, but also by the macroeconomic factors.
\end{abstract}

Keywords: Debt maturity structure, Inflation, GDP growth rate, Money supply, Macro-tax burden

Foreign scholars' empirical study of the influencing factors of the debt maturity structure started in the middle term of 1990s, and in numerous empirical literatures, the representative researches included Barclay and Smith's study (Barclay M J, 1995, P.609-6315), Stohs and Mauer's study (Stohs M H, Mauer D C, 1996, P.279-312), and Guedes and Opler's study (Guedes J, 1996, P.1809-1833). Their studies showed that the interior factors such as the enterprise size, the bond rating, and the corporate growth opportunity would all influence the debt maturity structure. Some other scholars such as Demirguc-Kunt \& Maksimovic (Demirguc-Kunt A, 1999, P.295-336), Antoniou, Guney \& Paudyal (Lei, 2004), Fan \& Titman (Fan P H, 2004) studied the influencing factors of the debt maturity structure from the financial and political environment, the national system, the national law system, the taxation system, the information environment, and the capital providers' character. Chinese scholars such as Sun Zheng, Liu Fengwei, and Li Zengquan (Liu, 2005, P.52-63) empirically analyzed the influence of the system factor on the debt maturity structure. Because the actual environment of the listed companies in China is largely different with the environment in developed countries, the macro environment may be the important factor for enterprises to select different debt maturity structures.

\section{Research hypotheses}

In the incomplete capital market theory, the asymmetry degree of information and the agency cost would be much lower in the flourish term of economy, but they would be much higher in the winter of economy. That means in the winter of economy, creditors would face large risk, and the debt maturity is longer, the risk will be bigger, so creditors would more select those debts with short maturity, and on the contrary, in the flourish term, the long-term debts more easily occur.

Hypothesis 1: The GDP growth rate is positively correlated with the debt maturity structure.

Inflation is the process that the price continually rises and the money continually depreciates, and it has the effect that the fortune could be redistributed. Foreign scholars thought that the participators in the credit market, whether the creditors or the debtors, all believed that they could exactly predict the short-term change of the inflation in the inflatable term, but they could not grasp the long-term change of the inflation, so in this situation, those participators in the credit market only would make short-term debt contract.

Hypothesis 2: The inflation rate is negatively correlated with the debt maturity structure.

The money supply, i.e. the money stock, means the money sum serving for the society and the economy in the special term. When the money supply rises, the nominal interest rate will descend, and the enterprise debt service burden will be reduced, and the cash flow will ascend, and the non-monetary financial asset price will ascend, so the possibility that the reverse selection and the demoralization will be reduced, and the bank risk degree will be reduced, which may promote the application of the long-term loan to some extent, and the increase of the money supply will positively push the debt maturity, i.e. the money supply is positively correlated with the debt maturity. 
But on the other hand, the increase of the money supply means enterprises have more investment chances, and based on the view of the agency cost theory, those enterprises with more investment chances would select the short-term debts to reduce the agency costs because of deficient investments or the excessive investments. So the increase of the money supply will promote the use of the short-term debts, and the money supply is negatively correlated with the debt maturity.

Hypothesis 3: The money supply is negatively correlated with the debt maturity structure.

The macro-tax burden means the total tax rate level of one country. The influence of the macro-tax burden on the selection of the debt maturity structure is mainly embodied in the enterprise investment. The decrease of the macro-tax burden could enhance the enterprises' anticipation for the profitability, and strengthen their enthusiasm to invest. The enhancement of the macro-tax burden could restrain enterprises' enthusiasm of investment, and according to the agency cost theory, it will extend the debt maturity of enterprise, i.e. the macro-tax burden is positively correlated with the debt maturity.

Hypothesis 4: The macro-tax burden is positively correlated with the debt maturity structure.

\section{Sample selection and description}

The sample data come from the listed company in China from 1999 to 2005, and the financial listed companies and the listed companies of ST and PT are eliminated.

When testing the influence of the macro factors on the debt maturity structure, the interior characters of enterprise should also enter into the model. According to the formers' research, these factors include the company size, the growth rate, the profitability, and the asset maturity.

$\Delta$ GDP denotes the GDP growth rate, and the CPT denotes the inflation rate, and the money supply and the macro-tax burden respectively are denoted by MS and MTB.

\section{Model design and test result}

(1) The enterprise interior character factor and the debt maturity structure

Model 1 is the regression model which only considers the interior factors of enterprise.

$$
\mathrm{DM}=\beta_{0+} \beta_{1 \times \mathrm{SIZE}+} \beta_{2 \times \mathrm{M} / \mathrm{B}^{+}} \beta_{3 \times \mathrm{ROE}+} \beta_{4 \times \mathrm{AM}+} \varepsilon
$$

Table 2 shows the coefficients, the test results, and the fitting result of the regression equation, and the SIZE is positively correlated with the debt maturation, and it is significant one the level of 0.01 , according with the hypothesis of the agency cost. So the company with small size will always face higher trading cost and agency cost, so the companies with bigger size will select the longer debt maturity. AM is positively correlated with debt maturity, which indicates that longer asset maturity corresponds with longer debt maturity, and it is significant on the level of 0.01 , according with the time limit matching hypothesis. $\mathrm{M} / \mathrm{B}$ is negatively correlated with the debt maturity, and it is significant on the level of 0.01 , which indicates that the listed companies with more growth selection rights would possess more short-term debts, according with the anticipation. ROE is positively correlated with the debt maturity structure, and it could not significantly influence the debt maturity structure. First, when enterprises make the decision to select the long-term or short-term debt, and the factor of profitability is not the key factor to determine the decision. Second, in China, for a long term, the profitability of enterprise has been a important symbol index to reflect the quality of enterprise, and relatively, it is indirect to apply the debt maturity to transfer the quality symbol, so whether banks or the market rarely evaluate one enterprise by the debt maturity of this enterprise.

(2) The GDP growth rate and the enterprise debt maturity structure

By introducing the GDP growth rate into the regression model, the regression model is

$$
\mathrm{DM}=\beta_{0+} \beta_{1 \times \mathrm{SIZE}+} \beta_{2 \times \mathrm{M} / \mathrm{B}^{+}} \beta_{3 \times \mathrm{ROE}+} \beta_{4 \times \mathrm{AM}+} \beta_{5} \Delta_{\mathrm{GDP}+} \varepsilon
$$

From Table 4 , in the regression model, $\Delta$ GDP is negatively correlated with the enterprise debt maturity, which is reverse with the hypothesis of this article, and the test result is significant on the level of 0.05 . In the special system environment of China, the GDP is higher, the economic situation is better, and the investment chances are more, and when facing more investment chances, banks still provide the short-term loans because of risks, so the enterprise debt structure is the short-term debt maturity. 
(3) The inflation and the enterprise debt maturity structure

The regression model introducing the inflation factor is

$$
\mathrm{DM}=\beta_{0} \beta_{1 \times \mathrm{SIZE}+} \beta_{2 \times \mathrm{M} / \mathrm{B}^{+}} \beta_{3 \times \mathrm{ROE}+} \beta_{4 \times \mathrm{AM}+} \beta_{6 \mathrm{CPI}+} \varepsilon
$$

Table 5 shows that when the model is introduced by the variable of inflation, the fitting degree of the model is enhanced when only considering the interior factor of enterprise. The inflation rate denoted by CPI is negatively correlated with the debt maturity, and it is significant on the level of 0.1 , which indicates that the debt maturity structure of China would be reduced with the occurrence of inflation, and the use of short-term debt could reduce the uncertainty of the real value of the debt return, according with the hypothesis of anticipation.

(4) The money supply and the enterprise debt maturity structure

The regression model introducing the money supply factor is

$$
\mathrm{DM}=\beta_{0+} \beta_{1 \times \mathrm{SIZE}+} \beta_{2 \times \mathrm{M} / \mathrm{B}+} \beta_{3 \times \mathrm{ROE}+} \beta_{4 \times \mathrm{AM}^{+}} \beta_{7 \mathrm{MS}^{+}} \varepsilon
$$

Table 6 shows that when the money supply is introduced into the model, the fitting degree of the model could be enhanced. In Table 6, MS is negatively correlated with the debt maturity, and it is significant on the level of 0.01 , according with the anticipation hypothesis of this article, i.e. though the money supply may influence the debt maturity from two directions, but in China, the negative influence is more significant.

(5) The macro-tax burden and the enterprise debt maturity structure

The regression model introducing the macro-tax burden factor is

$$
\mathrm{DM}=\beta_{0} \beta_{1 \times \mathrm{SIZE}+} \beta_{2 \times \mathrm{M} / \mathrm{B}^{+}} \beta_{3 \times \mathrm{ROE}+} \beta_{4 \times \mathrm{AM}+} \beta_{8} \mathrm{MTB}+\varepsilon
$$

Table 7 shows that when the variable of the macro-tax burden is introduced in the model, the fitting degree of the model is enhanced when only considering the interior factor of enterprise. In the table, MTB is positively correlated with the debt maturity, and it is significant on the level of 0.05 , according with the research hypothesis in this article, i.e. the higher macro-tax burden level would restrain the investment chances and enthusiasm of enterprises and the debt maturity is longer.

\section{Conclusions}

Four representative macro economic gross indexes are selected in this article, and based on the qualitative analysis, the linear regression method is applied to introduce these four macro economic indexes into the original model with only interior characters of enterprise, and test their relationships with the debt maturity structure. The result indicates that these factors could significantly influence the debt maturity structure. The GDP growth rate is positively correlated with the debt maturity, and the inflation rate is negatively correlated with the debt maturity, and the money supply is negatively correlated with the debt maturity, and the macro-tax burden is positively correlated with the debt maturity, which means that the macro-tax burden is heavier and the debt maturity of enterprise is longer.

\section{References}

Barclay M J, C W Smith Jr. (1995). The Maturity Structure of Corporate Debt. Journal of Finance, No.50, P.609-631.

Demirguc-Kunt A, Maksimovic V. (1999). Institutions, Financial Markets and Firm Debt Maturity. Journal of Financial Economics, No.54, P.295-336.

Fan P H, Titman S, \& Twite G. (2004). An International Comparison of Capital Structure and Debt Maturity Choices. SSRN Wording Paper.

Guedes J, T Opler. (1996). The Determinants of the Maturity of Corporate Debt Issues. Journal of Finance. No.51. P.1809-1833.

Lei, Sen. (2004). Study on the Enterprise Debt Maturity Structure of China Based on Financial Repression. Chongqing: Thesis of Chongqing University.

Liu, Zheng, Liu, Fengwei \& Li, Zengquan. (2005). Marketization Degree, Government Intervention, and Enterprise Debt Maturity Structure. Economic Research Journal. No.5. P.52-63. 
Stohs M H, Mauer D C. (1996). The determinants of corporate debt maturity structure. Journal of Business. No.69. P.279-312.

Table 1. Total characteristics of listed companies' debt financing structure (\%)

\begin{tabular}{l|c|c|c|c|c|c|c}
\hline $\begin{array}{l}\text { Year } \\
\text { Index }\end{array}$ & 1999 & 2000 & 2001 & 2002 & 2003 & 2004 & 2005 \\
\hline Debt-to-assets ratio & 44.98 & 47.17 & 48.26 & 50.26 & 52.66 & 53.65 & 55.08 \\
$\quad$ Current debt ratio & 84.00 & 83.23 & 83.68 & 84.50 & 84.11 & 85.02 & 84.97 \\
Long-term debt ratio & 16.00 & 16.77 & 16.32 & 15.50 & 15.89 & 14.98 & 15.03 \\
\hline
\end{tabular}

Note: The bank credit ratio is the ratio between the sum of the long and short debts and the total debts.

Table 2. Definition of the independent variables and the expectant symbols

\begin{tabular}{c|c|c}
\hline Variables & $\begin{array}{c}\text { Expectant } \\
\text { symbols }\end{array}$ & Computation formula \\
\hline $\begin{array}{c}\text { Company size } \\
\text { (SIZE) }\end{array}$ & + & Natural logarithm of the total assets \\
Growth (M/B) & - & (Total assets book value - outstanding share equity + outstanding shares $\times$ \\
Profitability \\
(ROE)
\end{tabular}

Note: "--" denotes that the data come from the Statistic Yearbook.

Table 3. Result of linear regression

\begin{tabular}{|c|c|c|c|c|c|c|}
\hline \multirow[t]{2}{*}{ Model } & & \multicolumn{2}{|c|}{$\begin{array}{l}\text { Non-standardized } \\
\text { Coefficients }\end{array}$} & \multirow{2}{*}{$\begin{array}{c}\begin{array}{c}\text { Standardized } \\
\text { Coefficients }\end{array} \\
\text { Beta }\end{array}$} & \multirow[t]{2}{*}{$\mathrm{t}$} & \multirow[t]{2}{*}{ Sig. } \\
\hline & & B & Std. Error & & & \\
\hline \multirow[t]{5}{*}{1} & (Constant) & -.913 & .111 & & -8.231 & .000 \\
\hline & SIZE & .092 & .011 & .224 & 8.259 & .000 \\
\hline & $\mathrm{AM}$ & .409 & .020 & .469 & 19.973 & .000 \\
\hline & $\mathrm{M} / \mathrm{B}$ & -.042 & .009 & -.122 & -4.535 & .000 \\
\hline & $\mathrm{ROE}$ & .001 & .006 & .003 & .147 & .883 \\
\hline
\end{tabular}

$$
\text { Model Summary }
$$

\begin{tabular}{c|c|c|c|c}
\hline Model & $\mathrm{R}$ & R Square & Adjusted R Square & Std. Error of the Estimate \\
\hline 1 & .528 & .279 & .277 & .1415296 \\
\hline
\end{tabular}


Table 4. Result of linear regression

\begin{tabular}{|c|c|c|c|c|c|c|c|}
\hline \multirow{2}{*}{ Model } & & & \multicolumn{2}{|c|}{$\begin{array}{c}\text { Non-standardized } \\
\text { Coefficients }\end{array}$} & \multirow{2}{*}{$\begin{array}{c}\text { Standardize } \\
\text { Coefficients } \\
\text { Beta }\end{array}$} & \multirow{2}{*}{$\mathrm{t}$} & \multirow{2}{*}{ Sig. } \\
\hline & & & B & Std. Error & & & \\
\hline \multirow[t]{6}{*}{1} & (Con & & -.829 & .118 & & -7.030 & .000 \\
\hline & $\mathrm{SI}^{2}$ & & .093 & .011 & .227 & 8.367 & .000 \\
\hline & A & & .408 & .020 & .467 & 19.933 & .000 \\
\hline & $\mathrm{M}$ & & -.035 & .010 & -.101 & -3.529 & .000 \\
\hline & $\mathrm{RC}$ & & .001 & .006 & .003 & .139 & .890 \\
\hline & $\Delta c$ & & -.009 & .004 & -.053 & -2.092 & .037 \\
\hline \multicolumn{8}{|c|}{ Model Summary } \\
\hline Model & $\mathrm{R}$ & \multicolumn{2}{|c|}{ R Square } & \multicolumn{2}{|c|}{ Adjusted R Square } & \multicolumn{2}{|c|}{ Std. Error of the Estimate } \\
\hline 1 & .531 & \multicolumn{2}{|c|}{.281} & \multicolumn{2}{|c|}{.279} & \multicolumn{2}{|c|}{.1413009} \\
\hline
\end{tabular}

Table 5. Result of linear regression

\begin{tabular}{|c|c|c|c|c|c|c|c|}
\hline \multirow{2}{*}{ Model } & & \multicolumn{2}{|c|}{$\begin{array}{c}\text { Non-standardized } \\
\text { Coefficients }\end{array}$} & \multicolumn{2}{|c|}{$\begin{array}{c}\text { Standardized } \\
\text { Coefficients }\end{array}$} & \multirow{2}{*}{$\mathrm{t}$} & \multirow{2}{*}{ Sig. } \\
\hline & & $\mathrm{B}$ & Std. Error & & Beta & & \\
\hline \multirow[t]{6}{*}{1} & (Constant) & -.500 & .270 & \multirow{2}{*}{\multicolumn{2}{|c|}{.227}} & -1.849 & .065 \\
\hline & SIZE & .094 & .011 & & & 8.362 & .000 \\
\hline & AM & .408 & .020 & \multicolumn{2}{|r|}{.468} & 19.940 & .000 \\
\hline & $\mathrm{M} / \mathrm{B}$ & .038 & .009 & \multicolumn{2}{|r|}{.112} & 4.072 & .000 \\
\hline & ROE & .001 & .006 & \multicolumn{2}{|r|}{.004} & .190 & .850 \\
\hline & CPI & -.004 & .002 & \multicolumn{2}{|c|}{-.041} & -1.679 & .093 \\
\hline \multicolumn{8}{|c|}{ Model Summary } \\
\hline Model & $\mathrm{R}$ & R Square & \multicolumn{3}{|c|}{ Adjusted R Square } & \multicolumn{2}{|c|}{ Std. Error of the Estimate } \\
\hline 1 & .530 & .281 & \multicolumn{2}{|c|}{.278} & & \multicolumn{2}{|c|}{.1414341} \\
\hline
\end{tabular}


Table 6. Result of linear regression

\begin{tabular}{|c|c|c|c|c|c|c|}
\hline \multirow{2}{*}{ Model } & & \multicolumn{2}{|c|}{$\begin{array}{c}\text { Non-standardized } \\
\text { Coefficients }\end{array}$} & \multirow{2}{*}{$\begin{array}{c}\text { Standardized } \\
\text { Coefficients } \\
\text { Beta }\end{array}$} & \multirow{2}{*}{$\mathrm{t}$} & \multirow{2}{*}{ Sig. } \\
\hline & & $\mathrm{B}$ & Std. Error & & & \\
\hline \multirow[t]{6}{*}{1} & (Constant) & .019 & .442 & & .044 & .965 \\
\hline & SIZE & .093 & .011 & .226 & 8.338 & .000 \\
\hline & $\mathrm{AM}$ & .408 & .020 & .467 & 19.936 & .000 \\
\hline & $\mathrm{M} / \mathrm{B}$ & .033 & -.010 & -.097 & -3.322 & .001 \\
\hline & ROE & .001 & .006 & .003 & .136 & .892 \\
\hline & MS & -.070 & .032 & -.057 & -2.179 & .029 \\
\hline \multicolumn{7}{|c|}{ Model Summary } \\
\hline Model & $\mathrm{R}$ & R Square & \multicolumn{2}{|c|}{ Adjusted R Square } & \multicolumn{2}{|c|}{ Std. Error of the Estimat } \\
\hline 1 & .531 & .282 & \multicolumn{2}{|c|}{.279} & \multicolumn{2}{|c|}{.1413329} \\
\hline
\end{tabular}

Table 7. Result of linear regression

\begin{tabular}{c|c|c|c|c|c|c}
\hline \multirow{2}{*}{ Model } & \multirow{2}{*}{} & \multicolumn{2}{|c|}{$\begin{array}{c}\text { Non-standardized } \\
\text { Coefficients }\end{array}$} & $\begin{array}{c}\text { Standardized } \\
\text { Coefficients }\end{array}$ & \multirow{2}{*}{$\mathrm{t}$} & Sig. \\
\cline { 3 - 6 } & & $\mathrm{B}$ & Std. Error & Beta & & \\
\hline \multirow{2}{*}{1} & (Constant) & -.819 & .121 & & -6.775 & .000 \\
\hline & SIZE & .093 & .011 & .226 & 8.354 & .000 \\
\hline & AM & .408 & .020 & .467 & 19.915 & .000 \\
\hline & M/B & -.035 & .010 & -.101 & -3.526 & .000 \\
\hline & ROE & .001 & .006 & .002 & .100 & .921 \\
\hline & MTB & .007 & .003 & .050 & 1.963 & .050 \\
\hline
\end{tabular}

\begin{tabular}{c|c|c|c|c}
\hline Model & $\mathrm{R}$ & $\mathrm{R}$ Square & Adjusted R Square & Std. Error of the Estimate \\
\hline 1 & .530 & .281 & .279 & .1413798 \\
\hline
\end{tabular}

